\title{
Transkriptomik Veri Yaklaşımı ile Kutanöz Leyşmanyazisteki Moleküler Sinyal Yolakların ve Regülatör Moleküllerin Tanımlanması
}

\section{Defining the Molecular Signal Pathways and Upstream Regulators in Cutaneous Leishmaniasis with Transcriptomic Data Approach}

\author{
Özlem ULUSAN BAĞCl${ }^{1}\left(\right.$ ID), Ayşe CANER ${ }^{1,2,3,4}$ (ID) \\ ${ }^{1}$ Ege Üniversitesi Tıp Fakültesi, Tıbbi Parazitoloji Anabilim Dalı, İzmir. \\ ${ }^{1}$ Ege University Faculty of Medicine, Department of Parasitology, Izmir, Turkey. \\ ${ }^{2}$ Ege Üniversitesi, Sağlık Bilimleri Enstitüsü, Biyoinformatik Anabilim Dalı, İzmir. \\ 2 Ege University, Institute of Health Sciences, Department of Bioinformatics, Izmir, Turkey. \\ ${ }^{3}$ Ege Üniversitesi, Kanserle Savaş Uygulama ve Araştırma Merkezi, İzmir. \\ ${ }^{3}$ Ege University, Cancer Research Center, Izmir, Turkey. \\ ${ }^{4}$ Teksas Üniversitesi, MD Anderson Kanser Merkezi, Deneysel Tedavi Bölümü, Houston, TX, ABD. \\ ${ }^{4}$ The University of Texas, MD Anderson Cancer Center, Departments of Experimental Therapeutics, Houston, TX, USA.
}

Makale Atıfı: Ulusan Bağcı Ö, Caner A. Transkriptomik veri yaklaşımı ile kutanöz leyşmanyazisteki moleküler sinyal yolakların ve regülatör moleküllerin tanımlanması. Mikrobiyol Bul 2021;55(1):67-80.

\section{ÖZ}

Leyşmanyazis, hücre içi bir parazit olan Leishmania türlerinin etken olduğu bir hastalıktır. Parazitin türlerine ve konakçı immün tepkisine bağlı olarak, hastalıkların üç temel klinik formu; kutanöz, mukokutanöz ve viseral leyşmanyazis olarak adlandırılmaktadır. Kutanöz leyşmanyazis kronik bir hastalık olup ülserleşmiş̧ lezyonların varlığı ile karakterizedir. Hastalık sırasında oluşan cilt patolojisi, kısmen enfekte eden Leishmania türleriyle, aynı zamanda çeşitli klinik sonuçlara neden olan enflamatuvar ve anti-enflamatuvar konak immün yanıt faktörlerinin kombinasyonu ile belirlenmektedir. Bu çalışmada, Leishmania major ve Leishmania braziliensis'e karşı doğal dirençli ve duyarlı olan farelerde hastalığın patogenezi ile bağışıklık yanıtında rolü olan ve konak-parazit etkileşimlerini belirleyen genleri, moleküler sinyal mekanizmalarını ve moleküllerin biyolojik fonksiyonlarını belirlemek amaçlanmıştır. Bunun için, L.major/L.braziliensis ile enfekte ve sağlıklı farelerden elde edilmiş yirmi dört doku örneğinin ekspresyon profilini içeren GSE56029 kodlu transkriptomik veri seti "Gene Expression Omnibus" (GEO) veri tabanından elde edilmiştir. Daha sonra, $\mathrm{R}$ betiğinde limma paketi ile diferansiyel olarak eksprese edilmiş genler tanımlanmıştır. Analizlerde FDR $q<0.05$ ve mutlak $\log _{2}$ FC $>2$ eşik değer olarak kabul edilmiştir. Ardından diferansiyel olarak eksprese edilmiş genler için fonksiyonel ve yolak zenginleştirme analizleri "Ingenuity Pathway Analysis" (IPA) ile gerçekleştirilmiştir. Anlamlı derecede farklı seviyede eksprese edilen genlerin her biri için $p<0.01$, FDR q değeri< 0.01 ve mutlak $\log _{2} \mathrm{FC}>1$ kullanılarak IPA 8.0 yazılım programı ile analiz edilmiştir. Bu analizler ile en yüksek oranda zenginleştirilmiş yolakların enflamasyon, dendritik hücre olgunlaşması ve TREM-1 "Triggering Receptor Expressed on Myeloid Cells 1" (TREM-1) sinyal mekanizmaları olduğu ve bağışıkık 
sisteminin düzenlenmesiyle ilgili diferansiyel olarak eksprese edilmiş genlerin kutanöz leyşmanyazis seyri ile yakından ilişkili olduğu belirlenmiştir. Akım-yukarı regülatör analizi ile dokularda biyolojik aktivitelere neden olan gen ekspresyon değişikliklerini açıklayan regülatörün TNF- $\alpha$, IFNy, IL-1 $\beta$, IL-10RA ve "Signal Transducer and Activator of Transcription-1" (STAT-1) olduğu öngörülmüştür. Çalışmada ayrıca, antileishmanial etkiye sahip olabilecek kimyasal bileşikler de tanımlanmıştır. Bu çalışma ile direnç/duyarlıık fenotipini belirleyen parazit türlerine ve konağa ait mekanizmalar aydınlatılmaya çalışılmışı. L.major ve L.braziliensis ile enfekte olan BALB/c ve C57BL/6 farelerinde farklılık gösteren gen ekspresyon paternleri, sitokin/kemokinler ve sinyal yolaklarının değerlendirilmesi, enfeksiyonun altında yatan potansiyel mekanizmaları genetik açıdan daha iyi anlamamızı sağlayacaktır. Bu sonuçların kutanöz leyşmanyazisin tanı ve prognoz tahmini için potansiyel biyobelirteçlerin geliştirilmesi ve yeni tedavi hedefleri hakkında bilgi sağlaması açısından gelecek çalışmalar için yol gösterici nitelikte olabileceği düşünülmektedir.

Anahtar kelimeler: Leishmania spp.; gen ekspresyonu; moleküler sinyal yolağı; yukarı-akım regülatörleri; kutanöz leyşmanyazis.

\section{ABSTRACT}

Leishmaniasis is a disease caused by the genus Leishmania spp., which are intracellular parasites. Depending on parasite species and host immune response, there are three basic clinical forms of the disease: cutaneous, mucocutaneous, and visceral leishmaniasis. Cutaneous leishmaniasis is a chronic disease and characterized by the presence of ulcerated skin lesions. The type of skin pathology seen during disease is determined in part by the infecting Leishmania spp., but also by a combination of inflammatory and antiinflammatory host immune response factors resulting in diverse clinical outcomes. In this study, it was aimed to determine the genes, molecular signaling mechanisms and biological functions of the molecules that play a role in the pathogenesis of the disease and immune response and determine host-parasite interactions in mice that are naturally resistant and susceptible to Leishmania major and Leishmania braziliensis. For this, transcriptomic series GSE56029 was downloaded from "Gene Expression Omnibus" (GEO) data base, including expression profiling of twenty-four tissue samples that were recovered from both naive mice and mice (BALB/C, C57BL/6) infected with L.major and L.braziliensis. Then, "Differentially Expressed Genes" (DEGs) were identified by limma package in R script. FDR $\mathrm{q}<0.05$ and absolute $\log _{2} \mathrm{FC}>2$ as threshold values were accepted in the analysis. Subsequently, functional and pathway enrichment analyses were performed for the DEGs by "Ingenuity Pathway Analysis" (IPA). For each of DEGs, $\mathrm{p}<0.01$, FDR $\mathrm{q}<0.01$, and absolute $\log _{2} \mathrm{FC}>1$ were used and analyzed with the software program IPA 8.0. Ingenuity Pathway Analysis revealed the most enrichment pathways to be the inflammation, dendritic cell maturation and "Triggering Receptor Expressed on Myeloid Cells 1" (TREM-1) signal mechanisms and that the DEGs related to the regulation of immune system process were closely associated with the progress of cutaneous leishmaniasis. The upstream regulator analysis predicted that TNF- $\alpha$, IFNy, IL-1 $\beta$, IL-10RA and "Signal Transducer and Activator of Transcription-1" (STAT-1) are the regulators that explained gene expression changes causing biological activities in the tissues. Chemical compounds that may have anti-leishmanial effects were also identified in the study. In this study, the mechanisms belonging to the parasite species and host that determine the resistance/susceptibility phenotype were attempted to elucidate. Assessment of gene expression patterns, cytokine/chemokines, and signaling pathways in $\mathrm{BALB} / \mathrm{C}$ and $\mathrm{C} 57 \mathrm{BL} / 6$ mice infected with L.major and L.braziliensis will provide a better understanding of the potential mechanisms underlying infection from a genetic perspective. These results may guide for the future studies in terms of developing potential biomarkers for the diagnosis and prognosis prediction of cutaneous leishmaniasis and providing information about new treatment targets.

Keywords: Leishmania spp.; gene expression; molecular signal pathway; up-stream regulators; cutaneous leishmaniasis.

\section{Gíriş}

Leyşmanyazis, protozoa grubunda yer alan Leishmania parazitinin farklı türlerinin neden olduğu kompleks bir hastalık grubudur. Leishmania türüne göre enfeksiyon kutanöz, mukokutanöz veya viseral hastalıkla sonuçlanmaktadır ${ }^{1}$. Hastalığın kutanöz formu genel- 
likle kendiliğinden sınırlanmakla birlikte, bazen skar dokusuna bazen de ilerleyerek daha invaziv olan mukokutanöz formlara dönüşebilmektedir. Mukokutanöz leyşmanyaziste mukozaların tutulma ve sekonder bakterilerle enfekte olma eğilimi daha fazla olmaktadır. Kutanöz forma en sık L.tropica ve L.major (eski dünya) ile L.braziliensis'in (yeni dünya) neden olduğu bilinmektedir. Hastalığın ortaya çıkış şekli etken parazit türüne ve konağın bağışıklık yanıtına bağlıdır². Son 30 yılda L.tropica'nın farelerde deneysel kutanöz leyşmanyazis (KL) üzerine çok sayıda araştırma yapılmış ve bağışıklık yanıtta rol alan hücre tipleri, sinyal yolakları ve tedavide kullanılabilecek ilaç hedefleri gibi çok sayıda veri elde edilmiştir $^{3,4}$.

Leishmania spp. zorunlu hücre içi parazitler olup, enfeksiyonun kontrol altına alınabilmesi için etkin bir T hücre bağışıklık yanıtı gerektirmektedir. Th1 bağışıklık yanıtı baskın olanlarda enfeksiyona karşı direnç görülürken, Th2 bağışıklık yanıtı etkin olanlar enfeksiyona karşı duyarlıdır. Bununla beraber, Th1 bağışık mekanizmasında rol alan sitokinlerin veya sinyal yolaklarının Leishmania türleri arasında farklılık gösterdiği saptanmıştır. BALB/c fareleri L.major enfeksiyonunu kontrol etmede yetersiz kaldıkları için ilerleyici lezyonlar ve sistemik hastalık gelişmesine neden olmaktadır. BALB/c farelerde L.major'e karşı baskın olarak gelişen yanıt Th2 olup enfeksiyonda duyarlılığa neden olan IL-4 ve IL-10 fazla miktarda sentezlenmektedir ${ }^{5}$. C57BL/6,8,10 ve CBA gibi bazı farelerin L.major'e kromozomal olarak dirençli olduğu gösterilmiştir ${ }^{3}$. IL-4, IL-5 ve IL-13 aracılı Th2 bağışık yanıtı enfeksiyonlara duyarlılığa neden olurken; IL-12 aracılı, IFN $\gamma$ ve TNF$\alpha$ 'nın baskın olarak rol aldığı Th1 bağışık yanıtının enfeksiyonlara karşı dirençten sorumlu olduğu bildirilmiştir ${ }^{6,7}$. Son zamanlarda yapılan çalışmalarda durumun bu kadar basit ifade edilemeyeceği ve sitokinlerin düzenlenmesinde, duyarlılıkta veya kazanılmış dirençte başka mekanizmaların rol oynayabileceği gösterilmiştir ${ }^{3}$. L.braziliensis, L.major'un aksine $\mathrm{BALB} / \mathrm{c}$ farelerinde geçici, belli belirsiz bir cilt enfeksiyonuna neden olmaktadır ${ }^{8}$. Ayrıca C57BL/6 farelerinin L.braziliensis parazitine karşı doğal olarak dirençli olduğu belirtilmiştir $^{9}$. Fakat L.braziliensis immünolojisi üzerine yapılmış çalışmaların sayısı oldukça azdır.

Bazı konaklar Leishmania türleri ile enfekte olduğunda semptomlar görülmemekte, ancak yine de parazite karşı bağışıklık meydana gelmektedir. Hastalığın bu şekilde sessiz geçirilmesinde özellikle CD4+ hücrelerinin etkinliğini azaltan regülatör T (Treg) hücrelerinin (CD4+-CD25+) rolü bulunmaktadır ${ }^{10}$. Treg hücrelerinin IL-10 düzeyini artırması sonucunda konak hücre arjinaz seviyesinde artış olmaktadır. Arjinaz seviyesindeki artış klasik yoldan makrofajları aktive eden NO seviyesinde azalmaya neden olmakta ve parazitin büyümesi ve proliferasyonunu sağlayan poliaminlerin miktarını artırmaktadır. Bu durumun tersi olarak Treg hücre ve IL-10 düzeylerinin azalması durumunda, efektör T hücre fonksiyonlarının artışına bağlı olarak lezyon gelişmediği, ancak enfeksiyona karşı gelişen bağışıklığın da kısa süreli olduğu belirtilmektedir ${ }^{10-12}$. Bununla beraber, Leishmania'ya karşı gelişen bağışık yanıt mekanizmalarının aydınlatılması için Leishmania türlerine duyarlı ve dirençli deneysel modellere ve bunların karşılaştırmalarına dair çalışmalara hala gereksinim duyulmaktadır.

Bu çalışmada, L.major'e doğal dirençli C57BL/6 ile duyarlı olan BALB/c ve L.braziliensis'e dirençli olan BALB/c ile C57BL/6 farelerinde hastalığın patogenezinde ve bağışık yanıtta 
rolü olan ve konak-parazit etkileşimlerini belirleyen genlerin, moleküler mekanizmaları ve genlerin/moleküllerin biyolojik fonksiyonlarının saptanması amaçlanmıştır. Böylece enfeksiyonun tanısında veya prognozda yol gösterici olabilecek ve ilaç hedefi olarak kullanılabilecek belirteçlerin saptanması hedeflenmektedir.

\section{GEREÇ ve YÖNTEM}

Bu çalışma, 2 Nisan-25 Mayıs 2020 tarihleri arasında gerçekleştirildi. Gen ekspresyon profili içeren GSE56029 matriks dosyası Gene Expression Omnibus (GEO; http://www. ncbi.nlm.nih.gov/geo/) veri tabanından elde edildi. Fonksiyonel genomik veriler içeren bu mRNA ekspresyon matriksine "GLP6885-Illumina Mouse (Ref-8 v2.0) ekspresyon beadchip" platformu ile mikrodizin yöntemi uygulandı. Bu platformdaki veri seti dört farklı leyşmanyazis fare modeli ve kontrol gruplarını içeren transkriptomik veriler şeklinde sunuldu. GEO veri bankasında, bu verilerin elde edilmesinde gerçekleştirilen deney protokolü şu şekildedir; a) L.major ile enfekte olan BALB/c fare grubu $(n=5)$, b) L.major ile enfekte $C 57 \mathrm{BL} / 6$ fare grubu $(\mathrm{n}=4)$, c) L.braziliensis ile enfekte olan BALB/c fare grubu $(n=4), d)$ L.braziliensis ile enfekte olan C57BL/6 fare grubu $(n=5)$, e) kontrol BALB/c fare grubu $(n=3), f)$ kontrol C57BL/6 fare grubu $(n=3)$ olmak üzere 24 fare kullanıldı. Leishmania enfeksiyonu, farelerin sağ kulaklarına $1 \times 10^{5}$ L.major veya L.braziliensis promastigotu enjekte edilerek oluşturuldu ve sonrasında lezyonların gelişimi açısından izlendi. Enfeksiyonun dördüncü haftasında kulak dokularından ve lezyonlardan alınan örneklerde RNA izolasyonu gerçekleştirildi, daha sonra tüm genom ekspresyon profill analizi uygulandı. Bu platforma ait ham veriler R programı (www.r-project.org, versiyon 3.6.2) kullanılarak ön işlem analizine tabi tutuldu ve normalize edildi. Leishmania ile enfekte ve kontrol grubu farelerin doku örnekleri arasındaki diferansiyel olarak eksprese edilmiş gen (DEG)'leri tanımlamak için limma paketi (http://www.bioconductor.org/packages/release/bioc/ html/limma.html, versiyon 3.42.2) kullanıldı ${ }^{13}$. Analizlerde yanlış pozitif oranı [False Discovery Rate (FDR)] q< 0.05 ve mutlak $\log _{2}$ kat değişimi $(F C)>2$ eşik değer olarak kabul edildi. DEG'lerin potansiyel biyolojik süreçlerini, hücresel bileşenlerini, fonksiyonlarını ve moleküler sinyal yolaklarını analiz etmek için Ingenuity Pathway Analizi (IPA) (www.ingenuity.com) kullanıldı. Anlamlı derecede farklı seviyede eksprese edilen genlerin her biri için $p<0.01$, FDR $q<0.01$ ve mutlak $\log _{2} F C>1$ kullanılarak IPA 8.0 yazılım programı ile analiz edildi. IPA sonuçları için elde edilen p değeri "Fischer Exact" testi ile değerlendirildi ve çoklu hipotez testi düzeltmesi için "Benjamini-Hochberg Correction" testi kullanıldı. Kontrol ve Leishmania ile enfekte fareler arasındaki gen ekspresyonlarının fonksiyonel ve biyolojik ağ analizini yapmak için "IPA-Core" analizi kullanıldı. DEG'lerin ilişkili oldukları moleküler sinyal yolları kanonik yolak analiz verileri ile regülatörler yukarı akım regülasyon (Up-stream Regulation) analizi ile tanımlandı. Daha sonra enfekte fare gruplarından elde edilen veriler için karşılaştırma analizi uygulandı ve sonuçlar 'heat-map' ile gösterildi. Grafiklerdeki aktivasyon/inhibisyon durumu Z skorlaması ile (turuncu renk skalası, aktivasyon; lacivert renk skalası, inhibisyon) belirlendi. Rengin koyuluğu aktivasyon veya inhibisyonun derecesini belirtmektedir. Genler arasındaki moleküler ilişkileri gösteren şekillerde; genler "düğüm" olarak sembolize edildi ve iki düğüm arasındaki biyolojik ilişki 
çizgisel olarak temsil edildi. Düğüm renginin yoğunluğu ekspresyon derecesini (kırmızı renk skalası, artmış ekspresyon; yeşil renk skalası, azalmış ekspresyon) göstermektedir. Kenarlar, literatürdeki veya IPA veri tabanında depolanan bilgilerden en az bir referansla desteklendi.

\section{BULGULAR}

Bu çalışmada, Leishmania ile enfekte ve kontrol grubu farelerin doku örnekleri arasındaki DEG'ler tanımlanmış, daha sonra bu veriler fonksiyonel zenginleştirme analizi ile değerlendirilmiş, enfeksiyonda rol oynayan moleküler sinyal yolakları ve regülatörler birbirleri ile karşılaştırılmıştır. Verilerin ön işlem analizi ile total 25697 probtan, genlere karşılık gelen 25284 veri elde edilmiştir. Bu genlerin $\log _{2}$ FC ve FDR değerleri ile örneklerindeki DEG'ler belirlenmiştir; kontrol grupları ile karşılaştırılma sonrası, 502 DEG (L.major-BALB/C), 484 DEG (L.major-C57BL/6), 531 DEG (L.braziliensis-BALB/C) ve 452 DEG (L.braziliensisC57BL/6) Leishmania ile enfekte farelerde tanımlanmış ve venn şeması ile gösterilmiştir (Şekil 1a). Fonksiyonel zenginleştirme analizi sonuçları Şekil 1'de detaylı olarak verilmiştir.

Dört grup fare enfeksiyon modellerine ait gen ekspresyon verileri kanonik yolak analiz ile değerlendirilmiştir. Elde edilen moleküler sinyal mekanizmalarının karşılaştırmalı analizi sonrası; dört grup farede 39 moleküler sinyal mekanizması tanımlanmıştır (absolut $\log$ p değeri> 1.3 z skoru> 3) (Şekil 1b,c). En yüksek oranda aktivasyonlar; enflamasyon sinyal yolağı, dendiritik hücre $(\mathrm{DH})$ olgunlaşması ve "Triggering Receptor Expressed on Myeloid Cells 1" (TREM-1) sinyal yolağında saptanmıştır. Enflamasyon sinyal yolağındaki en yüksek aktivasyon skoru L.major ile enfekte olan BALB/c farelerinde elde edilmiştir.

DH olgunlaşma yolağının L.major ile enfekte BALB/c'de en aktifken, diğer üç fare modelinde aynı düzeyde aktivasyona sahip olduğu bulunmuştur. Bununla birlikte, TREM-1 sinyal yolağı L.major ile enfekte fare gruplarında daha yüksek aktivasyon gösterdiği belirlenmiştir. Aktivasyon gösteren moleküler sinyal yolaklarının aksine, inhibisyon gösteren yolakların sayısı daha az olarak tespit edilmiştir: Kalsiyum sinyal yolağı, "Peroxisome Proliferator Activated Receptor" (PPAR) sinyal yolağı, "Programmed Death-1" (PD-1)/ "PDLigand 1" (PD-L1) sinyal yolağı, "Liver X Receptors-Retinoid X Receptors" (LXR-RXR) sinyal yolağı. Bu yolaklardan kalsiyum sinyal yolağı ve LXR/RXR sinyal yolağı L.braziliensis ile enfekte olan BALB/c farelerde; PPAR ve PD-1/PDL-1 sinyal yolağı L.major ile enfekte olan BALB/c farelerde daha yüksek oranda inhibe olmuştur. Sinyal yolaklarına ait absolut log p değerleri Şekil 1c'de gösterilmiş ve en anlamlı değiş̧ikliğin DH olgunlaşması, enflamasyon ve TREM-1 sinyal yolaklarında olduğu belirlenmiştir.

Leishmania enfeksiyonuna karşı dirençte T hücre yanıtı önemli rol oynamaktadır. Kanonik yolak analizinde Th1 yolağının yüksek seviyede aktivasyon skoru ve anlamlı istatiksel değere sahip olarak bulunmuştur. Th1 hücre yanıtında etkili olan DEG'leri içeren yolak şeması Şekil 2'de ayrıntılı olarak gösterilmiştir.

Yukarı akım transkripsiyon regülatörleri, veri kümesinde gözlenen gen ekspresyon değişikliklerin açıklamasını ve incelenen dokularda meydana gelen biyolojik aktiviteleri 
Transkriptomik Veri Yaklaşımı ile Kutanöz Leyşmanyazisteki Moleküler Sinyal Yolakların ve Regülatör Moleküllerin Tanımlanması

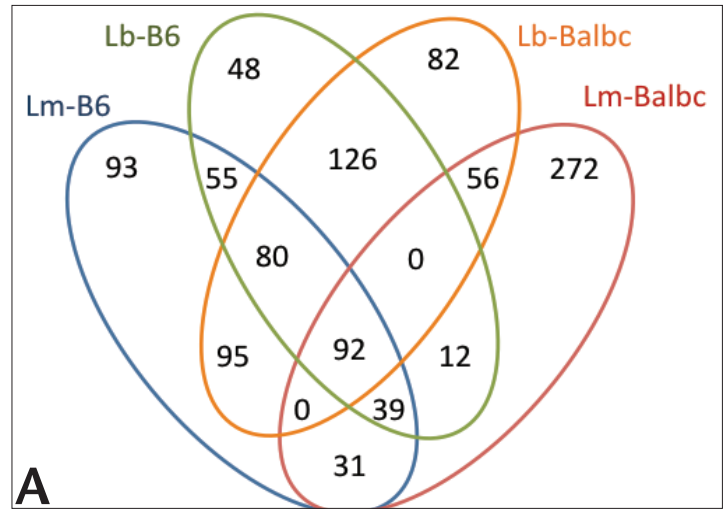

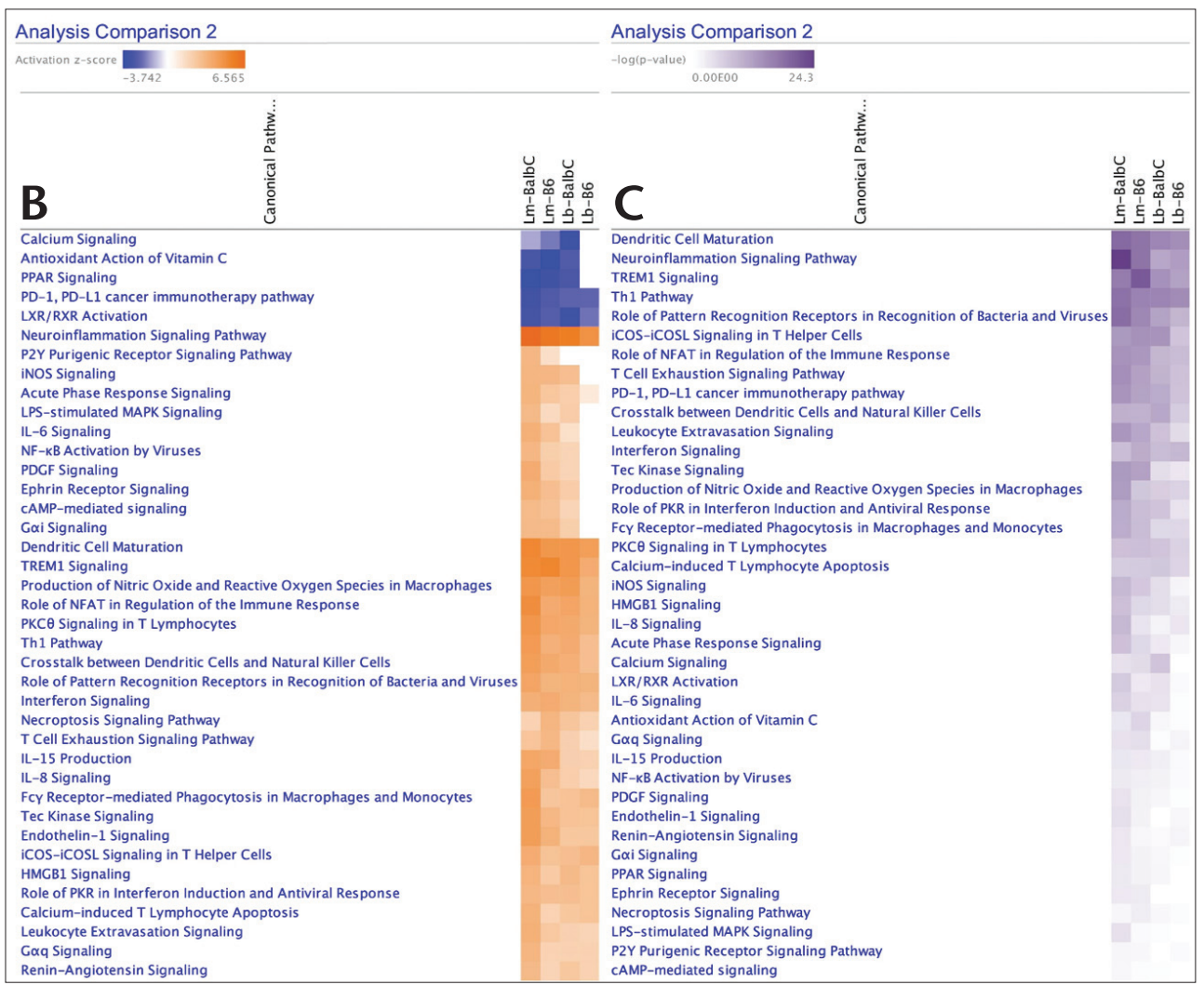

Şekil 1. Leishmania enfeksiyonunda rol oynayan DEG'ler ve sinyal yolakları. A. Leishmania ile enfekte farelerde DEG'leri gösteren venn şeması. B. Aktivasyon skorlarını (absolut z skoru> 3), C. P değerlerini gösteren heat-map grafiği (absolut log $p$ değeri> 1.3).

aydınlatmaya yardımcı olabilecek transkripsiyonel regülatörlerin kaskadını tanımlamaktır. Leishmania infeksiyonunda yukarı regüle edilmiş DEG'ler için, 47 aktif potansiyel gösteren yukarı akım regülatörü tanımlanmıştır (Şekil 3). Fare modellerinde TNF- $\alpha$, IFN $\gamma$, IL-1 $\beta$, IL- 


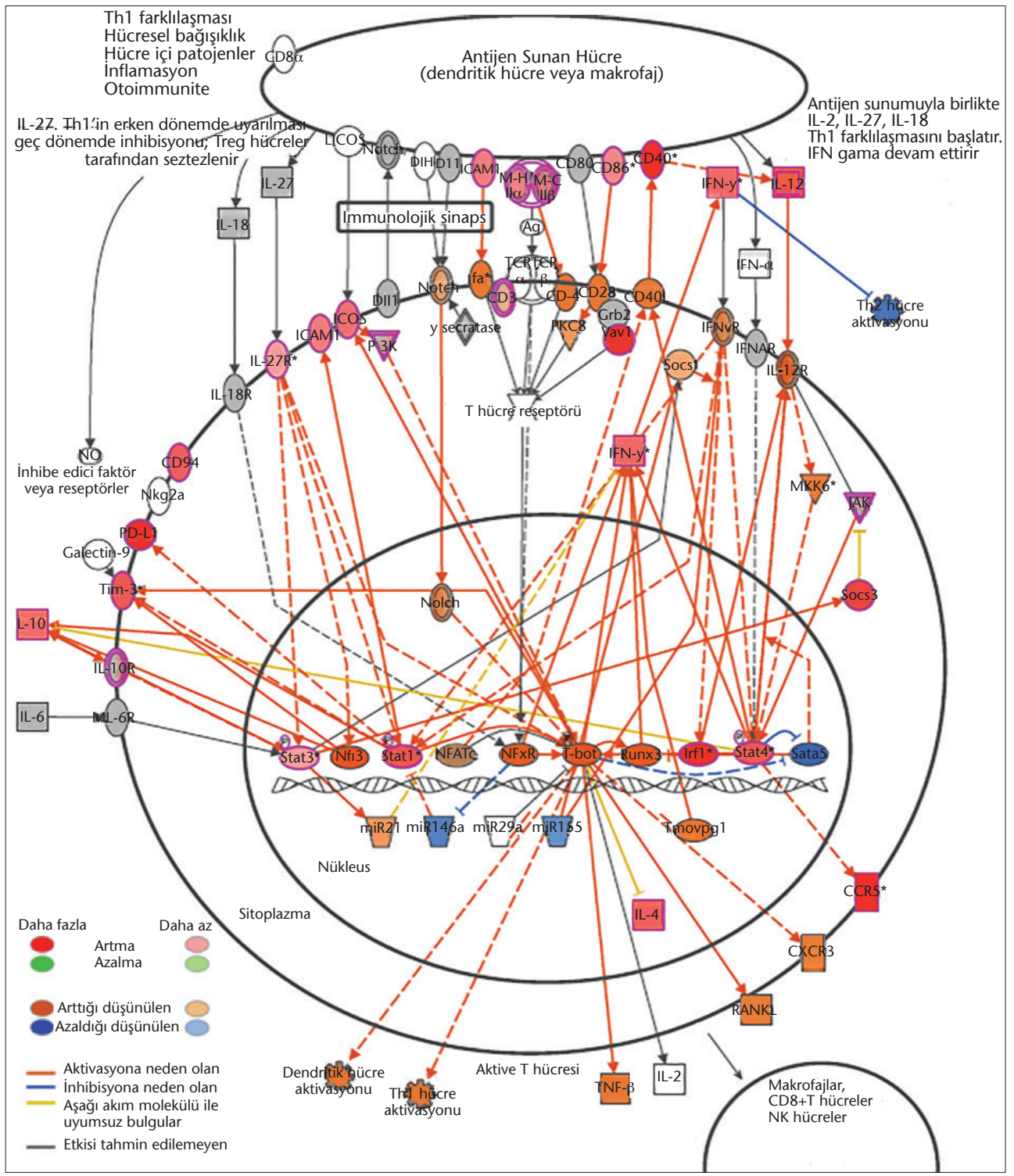

Şekil 2. Leishmania'ya karşı aktif rol oynayan Th1 hücre yanıt yolağı ve bu yolakta yer alan genlerin ekspresyonları (L.major ile enfekte olan BALB/c fare verilerinden elde edilmiştir). Her dügüum farklı bir yolu veya fonksiyonu temsil etmektedir. Kırmızı renkli düğümler, veriler içinde yukarı regüle olan DEG'leri; gri renkli düğümler, regülasyonunda değişikliklik olmayan genleri; renksiz düğümler, veri içinde olmayan genleri; mavi olan renkli düğümler, DEG'lere göre tahmin edilen inhibe olmuş genleri/fonksiyonlarl; turuncu olan renkli düğümler, DEG'lere göre tahmin edilen aktive olmuş düğümleri göstermektedir. Renk yoğunlukları DEG'deki aktivasyon ve regülasyon skorunu temsil etmektedir. Kenarlar, IPA tarafından onaylanmış olanlar turuncu (pozitif) ve mavi (negatif) renkler ile aktivasyon etkisi kesin olmayanlar gri renk ve aşağı akım molekülü ile uyumlu olmayanlar sarı renk ile ifade edilmiştir. 
Transkriptomik Veri Yaklașımı ile Kutanöz Leyșmanyazisteki Moleküler Sinyal Yolakların ve Regülatör Moleküllerin Tanımlanması

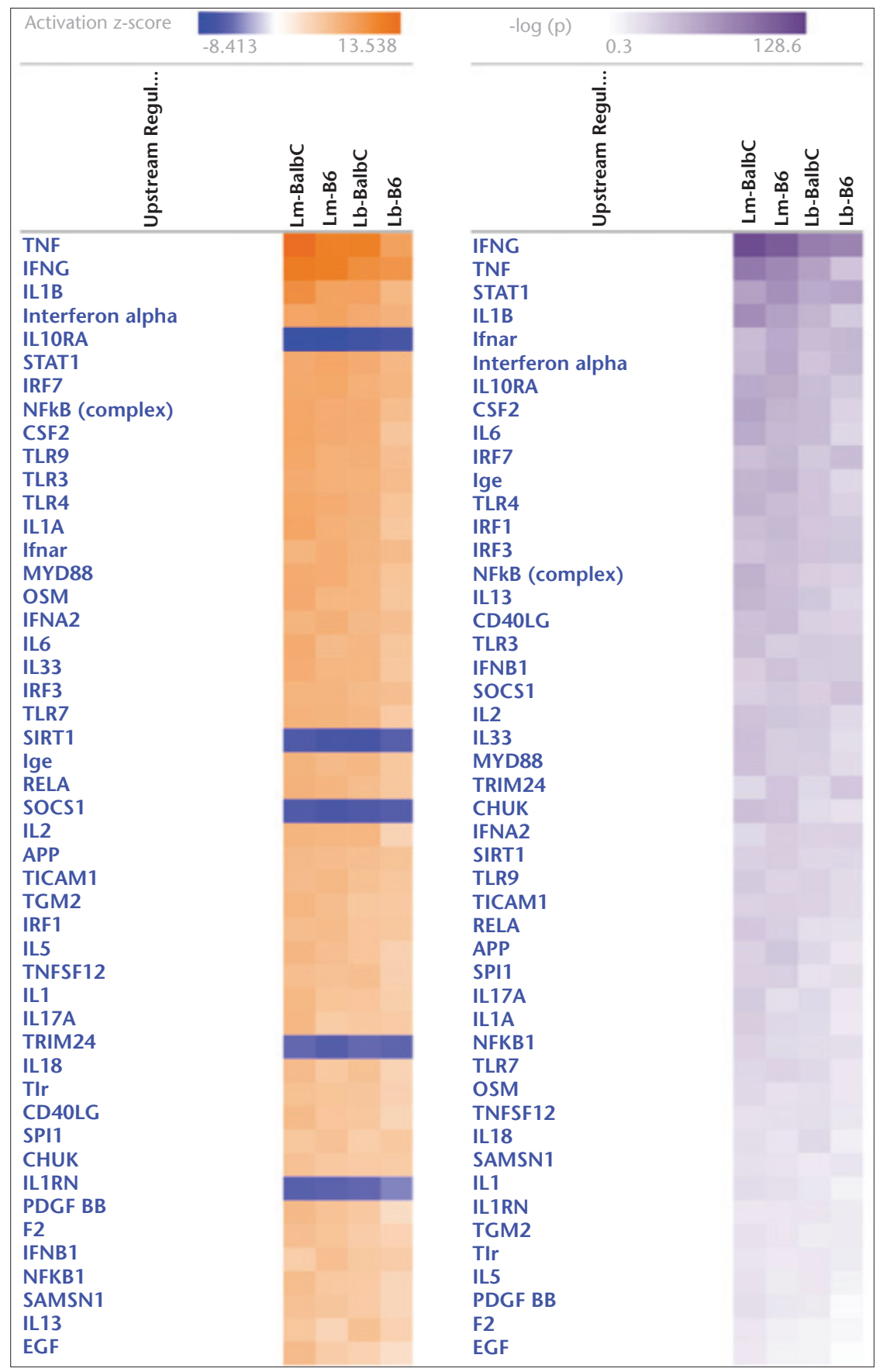

Şekil 3. Yukarı-akım transkripsiyon regülatörleri. A. Aktivasyon skorlarını (absolut z skoru> 5.5), B. $P$ değerlerini gösteren heat-map grafiği (absolut $\log p>1.5$ ). 


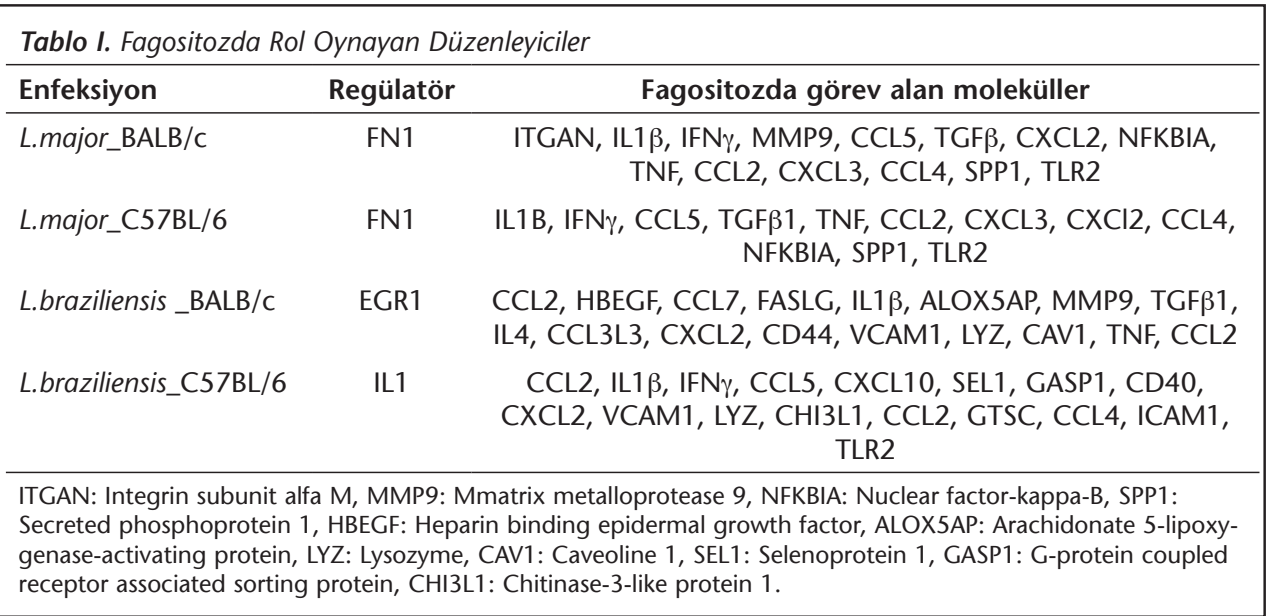

10RA, ve "Signal Transducer and Activator of Transcription-1" (STAT-1) yukarı-akım regülasyonunun önemli regülatörleri olarak belirlenen DEG'lerdir. Veri kümesinde, bu regülatörlerden IL-10RA'nın ekspresyon seviyesi belirgin olarak azalma gösterirken, diğerlerinde artış bulunmaktadır.

Leyşmanyazis enfeksiyonlarında fagositoz oldukça etkin bir mekanizmadır. Fagositozda, enfekte eden parazit türü ve konağa göre farklı sitokin ve kemokinler rol oynamaktadır. Tüm fare modellerinde fagositozda etkin rol üstlenen regülatörler Tablo I'de gösterilmiştir. L.major ile enfekte hücrelerde fagositoz süreci Leishmania amastigotlarının ekstrasellüler matriks elemanı olan fibronektine (FN) bağlanmasıyla başlamaktadır. L.braziliensis ile enfekte olan BALB/c farelerinde fagositoz sürecinin temelindeki faktör "Early Growth Response 1" (EGR1) iken, C57BL/6 farelerinde IL-1 rol oynamaktadır.

IPA bilgi veri tabanı kullanılarak, dört verinin karşılaştırmalı yukarı akış analizinde ilaç ve kimyasal bileşikler filtre edilmiştir. Bunun sonucunda, Leishmania enfeksiyon mekanizmasında bazı kimyasal bileşiklerin etkili rol oynadığı bulunmuştur. Bu bileşikler enfeksiyonun mekanizmasında regülatör olarak etki göstererek bazı fonksiyonları inhibe veya aktive edebilmektedir. Bu moleküllerden; imidazol türevi olan SB203580 ve flavonoid türevi olan PD98059, "Mitogen Activated Protein" (MAP) kinazı inhibe etmektedir. Alken türevi olan U0126 "Extracellular Signal-Regulated Kinases" (ERK) aktivasyonunun ve LY294002 "Phosphoinositide 3-Kinases" (PI3K)'nin inhibitörleri olarak etki göstermektedir. Bu moleküllerin ve dekzametazonun tüm fare modellerinde parazit yükü üzerinde inhibitör etkili olabileceği gösterilmiştir (Şekil 4).

\section{TARTIŞMA}

Dünyada 12-15 milyon kişi Leishmania spp. ile enfekte olup, her yıl 1.5 milyon yeni kutanöz leyşmanyazis olgusu görülmektedir ${ }^{14}$. L.major genellikle KL'ne yol açarken, L.braziliensis mukokutanöz leyşmanyazis tablosuna neden olmaktadır. Şimdiye kadar fare 


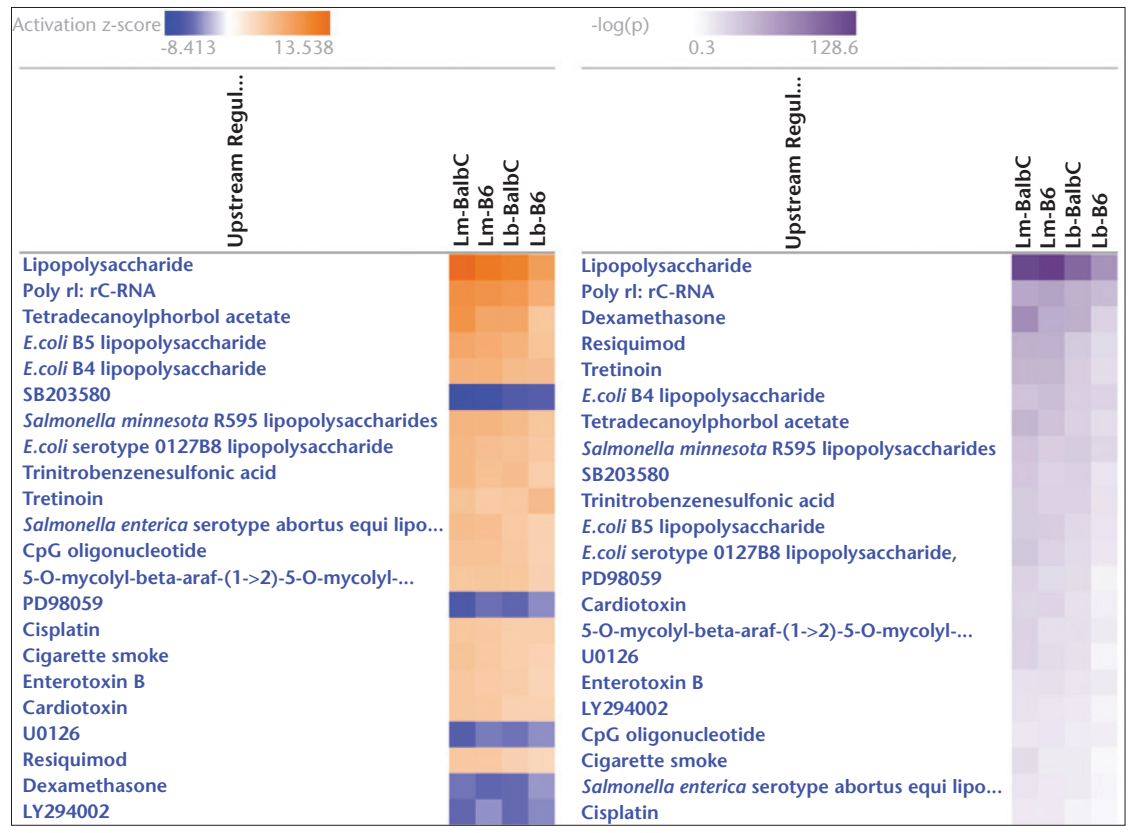

Şekil 4. Leishmania enfeksiyonunda rol onayan kimyasal bileşikler A. Aktivasyon skorlarını (absolut z skoru> 5), B. P değerlerini gösteren heat-map grafiği (absolut log p değeri> 1.5).

modelleri üzerinde L.major immünolojisini araştıran çalışmalar yapılmış olmasına rağmen L.braziliensis ile ilgili az sayıda araştırma bulunmaktadır ${ }^{3,6,8}$. Bu çalışma ile farelerde duyarlılık/direnç fenotiplerine yol açan gen ekspresyon profillerini, moleküler sinyal yolaklarını ve bağışıklık mekanizmalarının tanımlanması amaçlanmıştır.

Leishmania enfeksiyonunda T hücre yanıtı oldukça önemlidir. IL-12 ve IFN- $\gamma^{\prime}$ nın aktif olarak rol aldığı Th1 hücre yanıtında enfeksiyon ya hiç görülmemekte ya da çok hafif seyretmektedir. Enfeksiyona karşı dirençte oldukça önemli rol oynayan Th1 hücre yanıtı Şekil 2'de ayrıntılı olarak gösterilmiştir. IL-4 aracılı Th2 hücre yanıtı baskın olduğu zaman hastalık şiddetli seyretmekte ve progresyon göstererek sistemik hastalığa yol açabilmektedir. Son zamanlarda yapılan çalışmalarda durumun bu kadar basit olmadığı ve duyarlılık ve direnç fenotipinde farklı sitokin ve kemokinlerin ekspresyon seviyelerindeki değişikliklerinin rol oynadığı gösterilmiştir. Bununla birlikte, parazite karşı gelişen yanıtta hem parazite ait yapıların hem de konak hücre yanıtının önemli olduğu ve bunların hastalığın prognozunu etkilediği bildirilmiştir. Bu nedenle, çalışmada iki farklı Leishmania türünün iki farklı konakta neden olduğu bağışık yanıtta rol oynayan sinyal yolakları ve gen ekspresyonları araştırılmıştır.

L.major ve L.braziliensis ile enfekte farelerde en fazla aktivasyonu enflamasyon sinyal yolağı, DH olgunlaşması ve TREM-1 sinyal yolağı göstermiştir. TREM-1 nötrofil, monosit ve makrofajların yüzeyinde bulunan bir transmembran glikoproteindir. TREM-1'in 
nötrofil granüllerinin degranülasyonunu ve dolayısıyla fagositozu artırdığı bilinmektedir. Ayrıca, makrofajlarda antijen sunumunu ve T hücre aktivasyonunu da artırmaktadır ${ }^{15}$. Bu çalışmada, enfekte farelerde TREM-1 sinyali enfekte olmayan farelere göre daha aktif olup, en fazla aktivasyon skoru L.major ile enfekte farelerde saptanmıştır. Daha önce yapılan bir çalışmada benzer olarak, L.major'e duyarlı BALB/c farelerinde TREM-1 sinyalinde istatistiksel olarak anlamlı bir artış saptanmış ve bu sinyalin immün sistemi modüle ettiği bildirilmiştir ${ }^{16}$. Cotter ve arkadaşları ${ }^{17}$ tarafından yapılan çalışmada iyileşmeyen lezyonlar ile karakterize L.major ile enfekte BALB/c farelerinde nötrofillerin ve yüzeylerinde eksprese olan TREM-1 proteinin arttığı ve yüksek düzeyde saptanan TREM-1'in kötü prognoz göstergesi olabileceği belirtilmiştir. Bu nedenle, TREM-1 sinyal yolağını hedefleyen ilaçlar geliştirilmesinin $\mathrm{KL}$ tedavisine faydalı olabileceği düşünülmektedir. DH aktivasyonu L. major ile enfekte BALB/c fare dokularında en fazla oranda saptanmıştır. DH'ler profesyonel olarak antijen sunan hücreler olup, kazanılmış bağışıklığın merkezi olarak bilinmektedir. Leishmania ile karşılaşan $\mathrm{DH}^{\prime}$ ler T hücrelerinin bulunduğu yerlere göç ederek, gelişecek bağışıklık yanıtın türünü belirlemektedir. Enfeksiyon ile DH'ler tarafından IL-12 sentezlenirse bağışık yanıt Th1 yönünde gelişmekte ve parazite karşı direnç meydana gelmektedir. Ancak antijen sunumundan sonra IL-4 sentezinde artış görülürse IL-12 sentezi baskılanmakta ve enfeksiyona karşı duyarıılık görülmektedir ${ }^{18}$.

Enfekte olan konak dokularında kalsiyum sinyal yolağının inhibe olduğu saptanmıştır. Kalsiyum; Trypanasoma, Leishmania, Plasmodium gibi intrasellüler parazitlerin hayatta kalması için kritik bir molekül olarak belirtilmiştir ${ }^{19}$. Innhibe olan diğer bir düzenleyici sinyal mekanizmasının PPAR yolağı olduğu ve en fazla L.major ile enfekte olan BALB/c farelerinde inhibe olduğu gösterilmiştir. PPAR'ların $\alpha, \beta / \delta, \gamma$ olmak üzere üç alt tipi bulunmakta olup, sitokinlerin salgılanmasını düzenleyen transkripsiyon faktörlerini inhibe etmekte ve anti-enflamatuvar özellikler göstermektedir. PPAR- $\alpha$ NF-kB'ye bağlandığı zaman IL-6'nın sentezlenmesini engellemektedir ${ }^{20}$. Enfeksiyonun şiddetli seyrettiği L.major ile enfekte BALB/c'lerde antienflamatuvar patern gösteren PPAR sinyal yolağının daha yüksek bir skor ile inhibisyon göstermesi ve enflamasyon sinyal yolağının aktivasyon skorunun daha yüksek olması beklenen bir durumdur. Bağışıklıkta T hücre yanıtının uyarılabilmesi için kostimülasyon sinyalleri gerekli olup, bu sinyallerden en önemlisi B7-CD28 kompleksidir. Ancak vücudun kendi antijenlerine karşı yanıtın engellenmesi veya oluşan enflamatuvar yanıtın aşırıya kaçmaması için PD-1/PDL-1 gibi negatif düzenleyicilerin Th1 hücre yanıtını azalttığı ve Treg hücrelerin aktivitesini artırdığı gösterilmiştir ${ }^{21}$. LXR, RXR ile heterodimer oluşturan, yağ ve glikoz metabolizmasını düzenlemede etkin rolleri olan bir nükleer reseptör ailesidir. Son zamanlarda yapılan çalışmalar, bu reseptörlerin metabolizma ve bağışıklığın kesişim noktasında bulunduğunu ve anti-enflamatuvar rolleri olduğunu göstermiştir. LXR agonistlerinin T lenfosit, makrofaj bağışıkıı hücrelerini de kapsayacak şekilde anti-proliferatif özellikler göstermesi nedeniyle kanser ve otoimmün hastalıkların tedavisinde kullanılabileceğine dair çalışmalar bulunmaktadır 22,23 . Leishmania ile ilgili yapılan çalışmalarda ise LXR'nin deneysel olarak inhibe edilmiş farelerin L.infantum'a dirençli olduğunun saptanması LXR antagonistlerinin Leishmania profilaksisinde veya tedavisinde kullanılabileceğini düşündürmektedir ${ }^{24}$. 
Leishmania enfeksiyonunda aktif potansiyel gösteren regülatörlerin TNF- $\alpha$, IFN- $\gamma$, IL1- $\beta$, IL-10RA ve STAT-1 olduğu saptanmıştır. Bu regülatörlerin L.major ile enfekte BALB/C farelerde, L.braziliensis ile enfekte BALB/c farelere göre daha yüksek düzeyde eksprese olduğu görülmektedir. Bu durum, özellikle IFN- $\gamma$ açısından şaşırtıcı görünmekle birlikte, daha önce yapılan çalışmalarda alınan sonuçlar durumu açıklamaktadır. DeKrey ve arkadaşları $^{8}$ tarafından yapılan çalışmada, L.major ve L.braziliensis ile enfekte edilmiş BALB/C farelerin lenf nodu aspirasyon örneklerinde IFN- $\gamma$ ekspresyon seviyelerinde anlamlı bir farklılık saptanmamıştır. Bunun yanında, L.braziliensis ile enfekte farelerde IL-4'ün daha düşük seviyede sentezlendiği belirtilmiştir. Sonuçta iki tür arasındaki enfeksiyon seyrindeki farklılıkta IL-4'ün sitokin seviyesinin etkili olduğu belirtilmiştir. Veri setinin analizinde IL-4 gen ekspresyon seviyelerinde, enfekte BALB/c farelerde belirgin bir artış saptanırken enfekte C57BL/6 farelerde azalma saptanmıştır. IL-1 $\beta$ 'nin kutanöz leyşmanyazis enfeksiyonundaki rolü karışıktır. Bu sitokin Th1 hücre yanıtı ile birlikte konağı koruyucu etkiler gösterirken, aynı zamanda enfeksiyon bölgesine nötrofillerin toplanmasını artırarak doku hasarını şiddetlendirmekte ve lezyonun ilerlemesine neden olmaktadır ${ }^{25}$. Bu nedenle, enfeksiyona duyarlı olan ve enflamasyonun daha şiddetli seyrettiği L.major ile enfekte BALB/c farelerde IL-1 $\beta$ daha fazla eksprese olmaktadır. Paraziter enfeksiyonların kontrolünde IL-10 düzenleyici roller üstlenmekte olup, anti-enflamatuvar özellikler göstermektedir. T hücreleri üzerinde baskılayıcı fonksiyonları bulunmakta olup Leishmania enfeksiyonundaki lezyonların progresyonundan sorumludur ${ }^{26}$. Çalışmamızda dört fare grubunda da IL-10 seviyesinde azalma görülmüş̧tür.

Çalışmadaki analizler sonucunda Leishmania enfeksiyon mekanizmasında bazı kimyasal bileşiklerin inhibitör rol oynadığı bulunmuştur. Bunlardan SB203580 molekülü MAPK'ları hedeflemektedir. Leishmania'da şimdiye kadar tanımlanmış 17 tane MAPK bulunmasına rağmen, üç tanesinin (LmaMPK4, LmaMPK7, LmaMPKa10) fosforile olduğu ve amastigotların makrofajlar içerisinde yaşamını devam ettirmesini sağladıkları bildirilmiştir. SB203580 molekülünün LmaMPK10'u inhibe ettiği belirtilmiştir²7. Buna ek olarak, MAPK ailesinden olan ERK'in aktivasyonu IL-10 seviyesinde artışa ve Leishmania'ya karşı duyarlılığa neden olmaktadır. Bu nedenle ERK inhibitörü olan UO126 ve ERK'in pozitif düzenleyicisi MEK'in inhibitörü olan PD98059 moleküllerin tedavide kullanılabilecek ajanlar olduğu bildirilmiştir ${ }^{28}$. Leishmania parazitleri makrofajların fagositoz etkisine karşı koymak ve hücre içinde yaşamlarını sürdürebilmek amacıyla PI3K yolunu kullanmaktadır. LY294002 tarafından bu yolağın inhibe edilmesi parazitlerin fagosite edilmesini artırmaktadır ${ }^{29}$. Ayrıca analizler ile dekzametazonun enfekte farelerde parazit yükünü inhibe edebileceği saptanmıştır. Nyamao ve arkadaşları tarafından yapılan çalışmada ${ }^{30}$ L.major ile enfekte farelerden dekzametazon ve hidrokortizon uygulanan lezyonlarda belirgin gerileme olduğu, serumlarında IFN düzeylerinin daha yüksek olduğu saptanmıştır.

Şimdiye kadar yapılan çalışmalarda, Leishmania spp.'ye duyarlı farelerde Th2, dirençli farelerde Th1 bağışıklık yanıt tipinin etkin olduğu söylenmiştir. Ancak son zamanlarda Leishmania enfeksiyonuna karşı oluşan bağışık yanıtın çok daha kompleks olduğu, direnç/ duyarlıık fenotipini belirleyen parazit türlerine ve konağa ait çok sayıda mekanizmanın 
olduğu belirtilmiştir. Bu çalışma ile L.major ve L.braziliensis ile enfekte olan BALB/c ve C57BL/6 farelerinde farklılık gösteren gen ekspresyon paternleri, sitokin ve kemokinler ile sinyal yolakları değerlendirilerek mekanizmalar aydınlatılmaya çalışılmıştır. Bağışıklık mekanizmalarının daha iyi anlaşılmasıyla profilakside ve tedavide kullanılabilecek ilaçlar, prognoz göstergesi olabilecek belirteçler saptanabilecek, inmal edilmiş tropikal hastalıklar listesinde olan KL'in prevalansında ve morbiditesinde azalma sağlanabilecektir. Bu çalışmada, yeni tedavi molekülleri için hedef olabilecek genleri içeren sinyal yolakları ve inhibitör etki gösteren bileşikler tartışılarak, bunların gelecek çalışmalar için yol gösterici nitelikte olabileceği düşünülmektedir.

\section{ETIK KURUL ONAYI}

Herhangi bir hayvan veya insan örneği kullanılmaması sebebiyle bu çalışma için etik kurul onayı gerekmemektedir.

\section{ÇIKAR ÇATIŞMASI}

Yazarlar bu makale ile ilgili herhangi bir çıkar çatışması bildirmemişlerdir.

\section{KAYNAKLAR}

1. de Vries HJ, Reedijk SH, Schallig HD. Cutaneous leishmaniasis: recent developments in diagnosis and management. Am J Clin Dermatol 2015; 16: 99-109.

2. Andrade-Narváez FJ, Vargas-González A, Canto-Lara SB, Damián-Centeno AG. Clinical picture of cutaneous leishmaniases due to Leishmania (Leishmania) mexicana in the Yucatan peninsula, Mexico. Mem Inst Oswaldo Cruz 2001; 96(2): 163-7.

3. Nahidi S, Gholami E, Taslimi Y, Habibzadeh S, Seyed N, Daverpanah E, et al. The outcome of arginase activity inhibition in BALB/C mice hosting Leishmania tropica. Parasite Immunol 2020; 42: e12691.

4. Miramin-Mohammadi A, Javadi A, Eskandari SE, Mortazavi H, Rostami MN, Khamesipour A. Immune response in cutaneous leishmaniasis patients with healing vs. non-healing lesions. Iran J Microbiol 2020; 12(3): 249-55.

5. Reed SG, Scott P. T-cell and cytokine responses in leishmaniasis. Curr Opin Immunol 1993; 5: 524-31.

6. Bamorovat M, Sharifi I, Aflatoonian MR, Sadeghi B, Shafiian A, Oliaee RT, et al. Host's immune response in unresponsive and responsive patients with anthroponotic cutaneous leishmaniasis treated by meglumine antimoniate: A case-control study of Th1 and Th2 pathways. Int Immunopharmacol 2019; 69: 321-7.

7. Bogdan C, Gessner A, Sollbach W, Rollinghoff M. Invasion, control and persistence of Leishmania parasites. Curr Opin Immunol 1996; 8: 517-25.

8. DeKrey GK, Lima HC, Titus RG. Analysis of the immune responses of mice to infection with Leishmania braziliensis. Infect Immun 1998; 66: 827-9.

9. Samuelson J, Lerner E, Tesh R, Titus R. A mouse model of Leishmania braziliensis braziliensis infection produced by coinjection with sand fly saliva. J Exp Med 1991; 173: 49-54.

10. Belkaid Y, Piccirillo CA, Mendez S, Shevach EM, Sacks DL. CD4+CD25+ regulatory T cells control Leishmania major persistence and immunity. Nature 2002; 420(6915): 502-7.

11. Guimaraes ET, Santos LA, Ribeiro dos Santos R, Teixeira MM, dos Santos WLC, Soares MBP. Role of interleukin-4 and prostaglandin E2 in Leishmania amazonensis infection of BALB/C mice. Microbes Infect 2006; 8: 1219-26.

12. DeFranco A, Locksley RM, Robertson M. Immunity. The Immune Response in Infectious and Inflammatory Disease. Yale J Biol Med 2007; 80(3): 137. 
13. Ritchie ME, Phipson B, Wu D, Hu Y, Law CW, Shi W. Limma powers differential expression analyses for RNAsequencing and microarray studies. Nucleic Acids Res 2015; 43(7): e47.

14. Alvar J, Ve'lez ID, Bern C, Herrero M, Desjeux P, Cano JB, et al. WHO Leishmaniasis Control Team. Leishmaniasis worldwide and global estimates of its incidence. PLoS One 2012; 7: e35671.

15. Sharif O, Knapp S. From expression to signaling: roles of TREM-1 and TREM-2 in innate immunity and bacterial infection. Immunobiology 2008; 213: 701-13.

16. Ulusan Ö, Mert U, Sadıqova A, Öztürk S, Caner A. Identification of gene expression profiles in Leishmania major infection by integrated bioinformatics analyses. Acta Tropica 2020; 208: 105517.

17. Tacchini-Cottier F, Zweifel C, Belkaid Y, Mukankundiye C, Vasei M, Launois $P$, et al. An immunomodulatory function for neutrophils during the induction of a CD4+ Th2 response in BALB/C mice infected with Leishmania major. J Immunol 2000; 165: 2628-36.

18. von Stebut E, Belkaid Y, Jakob T, Sacks DL, Udey MC. Uptake of Leishmania major amastigotes results in activation and interleukin 12 release from murine skin-derived dendritic cells: implications for the initiation of anti-Leishmania immunity. J Exp Med 1998; 188(8): 1547-52.

19. Docampo R, Moreno SN, Plattner H. Intracellular calcium channels in protozoa. Eur J Pharmacol 2014; 739 : 4-18.

20. Tanaka T, Narazaki M, Masuda K, Kishimoto T. Regulation of IL-6 in Immunity and diseases. regulation of cytokine gene expression in ımmunity and diseases. Adv Exp Med Biol 2016; 79-88.

21. Habib S, El Andaloussi A, Elmasry K, Handoussa A, Azab M, Elsawey A, et al. PDL-1 blockade prevents T cell exhaustion, Inhibits autophagy, and promotes clearance of Leishmania donovani. Infect Immun 2018; 86(6).

22. Bensinger SJ, Bradley MN, Joseph SB, Zelcer N, Janssen EM, Hausneret MA, et al. LXR signaling couples sterol metabolism to proliferation in the acquired immune response. Cell 2008; 134: 97-111.

23. Vedin LL, Lewandowski SA, Parini P, Gustafsson JA, Steffensen KR. The oxysterol receptor LXR inhibits proliferation of human breast cancer cells. Carcinogenesis 2009; 30(4): 575-9.

24. Bruhn KW, Marathe C, Maretti-Mira AC, Nguyen H, Haskell J, Tran TA, et al. LXR deficiency confers Increased protection against visceral Leishmania infection in mice. PLoS Negl Trop Dis 2010; 4(11): e866.

25. Kautz-Neu K, Kostka SL, Dinges S, Iwakura Y, Udey MC, von Stebut E. IL1 signalling is dispensable for protective immunity in Leishmania-resistant mice. Exp Dermatol 2011; 20: 76-8.

26. Galdino H, Saar Gomes R, dos Santos JC, Pessoni LL, Maldaner AE, Marques SM, et al. Leishmania (Viannia) braziliensis amastigotes induces the expression of TNF- $\alpha$ and IL-10 by human peripheral blood mononuclear cells in vitro in a TLR4-dependent manner. Cytokine 2016; 88: 184-92.

27. Kumari S, Singh S, Saha B, Paliwal PK. Leishmania major MAP kinase 10 is protective against experimental L.major infection. Vaccine 2011; 29: 8783-7.

28. Yang Z, Mosser DM, Zhang X. Activation of the MAPK. ERK, following Leishmania amazonensis infection of macrophages. J Immunol 2006; 178: 1077-85.

29. Ruhland A, Leal N, Kima PE. Leishmania promastigotes activate PI3K/Akt signalling to confer host cell resistance to apoptosis. Cell Microbiol 2007; 9(1): 84-96.

30. Nyamao MR, Zipporah OL, Khayeka WC, Bernard NJ, Rebecca WW. Efficacy of glucocorticoids in controlling Leishmania major infecting Balb/c mice. J Infect Dis Immun 2014; 6(2): 10-8. 